\title{
THE MAIN INDICATORS OF INTERNAL DYNAMICS OF PSYCHOLOGICAL RESOURCE'S RICHNESS OF PERSONALITY
}

\section{Olena Shtepa ${ }^{1}$}

DOI: https://doi.org/10.30525/978-9934-26-002-5-42

Psychological resource's richness of personality is a new concept of modern personality psychology, which reveals the «reflexively conditioned ability of a person to transform the quantitative content of his psychological resources» [1, p. 314]. In our empirical study of the content of resource's richness, it was found that the macro components of resource's richness are psychological resource capacity, psychological well-being, tolerance to uncertainty, coherence, existential resources, the strength of character, resources of psychological survival, resources of relationships [1, p. 322]. These macro indicators were important for characterizing the strategizing of psychological resources by a person. However, attention should be paid to the micro-indicators of resource's richness, which, in our opinion, determine its internal dynamics, and thus can characterize the personality's ability to selffulfillment.

In the empirical study, 420 people took part in the reward of 21-67 rocks $(\mathrm{M}=42.3$ ) (of which $57 \%$ are women and $43 \%$ are men) (4-6 year students and university teachers, students of the Institute of pre-university and postgraduate education, students «University of the Third Age», small business entrepreneurs). Were used such psychodiagnostic methods: questionnaire of losses and acquisition of personal resources (developed by $\mathrm{N}$. Vodopyanova and M. Stein on the basis of the resource concept of psychological stress and «conservation of resources» by S. Hobfall), questionnaire of psychological resourcefulness of O. Shtepa, testquestionnaire of diagnostics of indicators of existential resources of personality E.R. questionnaire «Virtues and strengths of character» (adaptation by I. Burovikhina, D. Leontiev, E. Osin of the methodology Values in Action by K. Peterson and M. Seligman. in which resources are characterized as mechanisms of concretization of values and ways of acquiring virtues), questionnaire of strategies for overcoming crisis M. Laad's condition (the method allows to determine the resources of psychological survival of the person), the questionnaire of psychological well-being (adaptation of S. Karskanova's method by K. Riff) for definition of

\footnotetext{
${ }^{1}$ Ivan Franko National University of Lviv, Ukraine
} 
motivational resources, A. Antonovsky's coherence scale in adaptation of E. Osin, a technique of definition of (in) tolerance to the uncertainty of S. Baudelaire (adaptation of G. Soldatova, L. Schaigerova), methods of assessing and forecasting the psychological development of situations of interpersonal interaction $\mathrm{O}$. Bondarenko to determine the resources of relationships. The assumption about the indicators of the internal dynamics of the psychological resource's richness of personality concerning resources that, being part of the structure of resource's richness, are determinants of its general level and predictors.

To single out the indicators of the internal dynamics of the resource's richness of the personality, a discriminant analysis was carried out on the scale of the "general level of resource's richness of the personality», which, with the correctness of $75.2 \%$ with the Wilks' Lambda value $(0.82)$, showed that the main indicators of the internal dynamics of the resource's richness of the personality there are 13 resources related to resources, in fact, psychological, motivational, existential, forces of character, resources of relationships (Table 1 ).

The results of the discriminant analysis showed that the range of indicators of the internal dynamics of the resource's richness of an individual does not include coherence, resources of tolerance to uncertainty, resources of psychological survival, and personal resourceful of man. With the help of classification analysis (method Predictor Variable Rankings), it became possible to determine predictors of resource's richness from the most important discriminated psychological resources (Table 2).

Based on the results of the classification analysis, it can be argued that the main internal predictors of resource's richness are existential resources «meaning and acceptance» as well as the resources of psychological wellbeing "positive relationships with others» and «autonomy».

The application of stepwise regression analysis made it possible to reveal five internal determinants of resource's richness (Table 3).

The results of the regression analysis showed that the psychological resources «helping others» and «self-realization in the profession», as well as the resource of psychological well-being "positive relationships with others» affect the increase in the overall level of resource's richness of the personality. At the same time, the resource of psychological well-being «autonomy» and the existential resource «mercy» cause a decrease in the level of the resource's richness. 
Table 1

\section{Discriminant analysis results of the indicators of the internal dynamics of the resource's richness of the personality}

\begin{tabular}{|c|c|c|c|c|c|c|}
\hline $\begin{array}{l}\text { The indicators } \\
\text { of the internal dynamics } \\
\text { of the resource's richness }\end{array}$ & 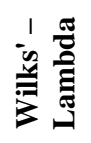 & 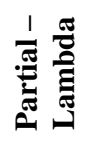 & 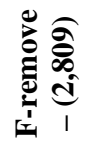 & $\frac{\bar{d}}{\grave{n}}$ & 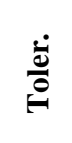 & 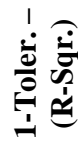 \\
\hline $\begin{array}{l}\text { Psychological resource «help } \\
\text { for others» }\end{array}$ & 0,862 & 0,95 & 20,70 & 0,00 & 0,68 & 0,31 \\
\hline $\begin{array}{l}\text { The existential resource } \\
\text { «meaning» }\end{array}$ & 0,838 & 0,97 & 8,91 & 0,00 & 0,59 & 0,40 \\
\hline $\begin{array}{l}\text { Strength of character } \\
\text { «prudence» }\end{array}$ & 0,835 & 0,98 & 7,81 & 0,00 & 0,67 & 0,32 \\
\hline $\begin{array}{l}\text { Psychological resource «self- } \\
\text { realization in the profession» }\end{array}$ & 0,835 & 0,98 & 7,41 & 0,00 & 0,72 & 0,27 \\
\hline $\begin{array}{l}\text { Resource of psychological } \\
\text { well-being «positive } \\
\text { relationships with others» }\end{array}$ & 0,832 & 0,98 & 5,96 & 0,00 & 0,61 & 0,38 \\
\hline $\begin{array}{l}\text { The resource of psychological } \\
\text { well-being «autonomy» }\end{array}$ & 0,833 & 0,98 & 6,85 & 0,00 & 0,68 & 0,31 \\
\hline $\begin{array}{l}\text { The existential resource } \\
\text { «mercy» }\end{array}$ & 0,831 & 0,98 & 5,61 & 0,00 & 0,76 & 0,23 \\
\hline $\begin{array}{l}\text { The existential resource } \\
\text { «acceptance» }\end{array}$ & 0,827 & 0,99 & 3,44 & 0,03 & 0,65 & 0,34 \\
\hline $\begin{array}{l}\text { Strength of character } \\
\text { «wisdom» }\end{array}$ & 0,833 & 0,98 & 6,46 & 0,00 & 0,71 & 0,28 \\
\hline $\begin{array}{l}\text { Strength of character } \\
\text { «persistence» }\end{array}$ & 0,828 & 0,98 & 4,34 & 0,01 & 0,68 & 0,31 \\
\hline $\begin{array}{l}\text { Psychological resource } \\
\text { «striving for wisdom» }\end{array}$ & 0,827 & 0,99 & 3,83 & 0,02 & 0,68 & 0,31 \\
\hline $\begin{array}{l}\text { Relationship resource } \\
\text { «psychosocial values (degree } \\
\text { of well-being)» }\end{array}$ & 0,827 & 0,99 & 3,74 & 0,02 & 0,87 & 0,12 \\
\hline $\begin{array}{l}\text { The strength of character } \\
\text { «interest in learning» }\end{array}$ & 0,826 & 0,99 & 3,05 & 0,04 & 0,81 & 0,18 \\
\hline
\end{tabular}

In order to identify the structure of indicators of the internal dynamics of resource's richness, multifactorial analysis of the allocated discriminated resources was carried out, which after four iterations showed a two-factor model of indicators of the internal dynamics of resource's richness of a person, explaining $66.2 \%$ of the variance. Factor 1 (36.8\%) included the existential resources of meaning and acceptance, which are the inner supports 
of the personality; in factor 2 (29.4\%) - the strength of character «wisdom», which conceptualizes the value of a philosophical understanding of life, and the psychological resource of self-realization in the profession, which allows a person to interpret his abilities as important for others.

Table 2

Classification analysis results of the indicators of the internal dynamics of the resource's richness of the personality (rang of predictor: $\min =0, \max =100$ )

\begin{tabular}{|l|c|}
\hline \multicolumn{1}{|c|}{$\begin{array}{c}\text { The indicators of the internal dynamics } \\
\text { of the resource's richness }\end{array}$} & $\begin{array}{c}\text { Rang of } \\
\text { predictor }\end{array}$ \\
\hline Psychological resource «help for others» & 37 \\
\hline Psychological resource «striving for wisdom» & 12 \\
\hline Psychological resource «self-realization in the profession» & 20 \\
\hline Resource of psychological well-being «positive relationships with others» & 97 \\
\hline The resource of psychological well-being «autonomy» & 87 \\
\hline The existential resource «meaning» & 100 \\
\hline The existential resource «mercy» & 46 \\
\hline The existential resource «acceptance» & 89 \\
\hline Strength of character «interest in learning» & 18 \\
\hline Strength of character «wisdom» & 26 \\
\hline Strength of character «persistence» & 15 \\
\hline Power of character «prudence» & 22 \\
\hline Relationship resource «psychosocial values (degree of well-being)» & 36 \\
\hline
\end{tabular}

Table 3

Regression analysis results of the indicators of the internal dynamics of the resource's richness of the personality

\begin{tabular}{|c|c|c|c|c|c|c|}
\hline $\begin{array}{c}\text { The indicators of the internal } \\
\text { dynamics of the resource's } \\
\text { richness }\end{array}$ & Фّँّ & 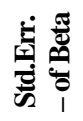 & $\oplus$ & 㼵 & 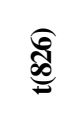 & $\frac{\bar{d}}{\frac{2}{2}}$ \\
\hline $\begin{array}{l}\text { Psychological resource «help } \\
\text { for others» }\end{array}$ & 0,196 & 0,035 & 0,059 & 0,01 & 5,55 & 0,00 \\
\hline $\begin{array}{l}\text { Psychological resource «self- } \\
\text { realization in the profession» }\end{array}$ & 0,117 & 0,035 & 0,039 & 0,01 & 3,29 & 0,00 \\
\hline $\begin{array}{l}\text { The resource of psychological } \\
\text { well-being «autonomy» }\end{array}$ & $-0,119$ & 0,036 & $-0,005$ & 0,00 & $-3,29$ & 0,00 \\
\hline $\begin{array}{l}\text { Resource of psychological well- } \\
\text { being «positive relationships } \\
\text { with others» }\end{array}$ & 0,146 & 0,038 & 0,006 & 0,00 & 3,76 & 0,00 \\
\hline The existential resource «mercy» & $-0,097$ & 0,035 & $-0,009$ & 0,00 & $-2,76$ & 0,00 \\
\hline
\end{tabular}


The results of the study allow us to formulate conclusions that the main indicators of the internal dynamics of the resource's richness of the individual are the existential resources «meaning» and «acceptance», which unfold the resource's richness for self-fulfillment; the resource of psychological wellbeing «positive relationships with others», which characterizes the purpose of resource's richness ; psychological resource "self-realization in the profession», which determines the scope of disclosure of human abilities; the resource of psychological well-being «autonomy», which causes the curtailment of resource's richness when a person strives for unproductive independence.

\section{References:}

1. Shtepa, O. S. (2020). Stratehii resursnoi nasychenosti osobystosti [The strategies of psychological richness of personality]. Problems of Modern Psychology: Collection of research papers of Kamianets-Podilskyi National Ivan Ohiienko University. G.S. Kostiuk Institute of Psychology of the National Academy of Educational Sciences of Ukraine / scientific editing by S.D. Maksymenko, L.A. Onufriieva. Issue 48. Kamianets-Podilskyi. doi: https://doi.org/10.32626/2227-6246.2020-48.313-338 